\title{
10
}

\section{Making the Invisible Seen: Putting Women's Rights on Vanuatu's Land Reform Agenda}

\author{
Anna Naupa
}

\begin{abstract}
Women in Vanuatu are at a cross road: they live in a society that is both traditional and modern ... The gendered roles imposed by society on women has [sic] seen them keep the traditions necessary for the continuation of the culture of their society (Piau-Lynch 2007: 4).

Kastom has dictated that men are the decision makers and women play a supportive or submissive role. This is often cited as the reason why women are not only involved in decision-making but also do not have a significant voice in the governance of their society. (Tor and Toka 2004: 9).
\end{abstract}

\section{Introduction}

Advocates of Melanesian women's rights have often struggled to find sympathetic audiences among the region's male-dominated societies. Resistance has been rationalised as preservation of cultural values and traditional notions of gendered behaviour, where gender equality advocates have been accused of undermining social cohesion and upsetting the delicate cultural ecosystem (Tor and Toka 2004). Women's traditional gendered roles as mothers and housewives has meant that few women enter positions of seniority in both public and private sectors, resulting 
in only a handful of champions for women's rights at the national level (Piau-Lynch 2007: 4). While Vanuatu can claim gender equality successes in areas most relevant to women's childcare roles (for example, health and education), there is still a long way to go in other areas (VNGOC 2007).

While land reform was a key political driver of Vanuatu's Independence in 1980, land policy reform only recently returned to the political arena in the mid-2000s. Finding the space to raise awareness about women's land rights in a Vanuatu land reform context is challenged by competing reform priorities, such as redress mechanisms for unscrupulous deals, customary conflict resolution, and anti-corruption measures that had been overlooked for a couple of decades. Predominantly viewed as a male domain, the absence of women is notable in land discussions. Women have been largely invisible in state-managed land decisions, not least due to exclusionary practices by the males who control access to land in the traditional arena. Compounded by the primacy of customary land practice enshrined by Vanuatu's Constitution and state reinforcement of such gender bias, advocating for women's land rights—and women's rights in general-has required culturally and politically strategic approaches to finding a place in the land reform agenda.

This paper analyses the different strategies used to raise awareness and advocate for the recognition of women's rights to land in Vanuatu's policy reform context. Given the cultural context in Vanuatu, it has been necessary to adopt an advocacy model that goes beyond framing the language of rights within accepted socio-cultural constructs, to also address the political-economic dimensions of gendered access to land through identifying male champions, and to combine both upstream (awareness-raising) and downstream (coalition-building) advocacy paths. Future advocacy efforts must include greater engagement by women themselves, not just their advocates, for reform efforts to be sustainable.

\section{Country Context}

The Republic of Vanuatu comprises 83 islands in a Y-shaped archipelago, lying south of Solomon Islands and west of Fiji, with a population currently estimated to be about 290,000, of which 48 per cent are women. It is considered to be a lower middle-income country, where the 
gross national income per capita was US\$3,000 in 2012. According to the World Bank's 'country policy and institutional assessment' ranking, Vanuatu scored 3.1 out of 6 for 'social inclusion/equity' in $2012 .{ }^{1}$

The majority of Ni-Vanuatu depend on what are described in Chapter 1 as 'land-based livelihoods', given that roughly three quarters of the population lives in rural areas, and 71 per cent of rural household incomes in 2010 were derived from subsistence production (39 per cent) or the sale of agricultural and other 'home made products' (GoV 2012a: 113-4). For countless generations, the land provided for all members of society, regardless of gender, sustained relationships between groups, and still underpins the identity and self-worth of most Ni-Vanuatu. Most $\mathrm{Ni}$-Vanuatu have access to land through customary systems, and this, combined with the richness of natural resources and social capital, has tended to buffer rural communities from some of the more extreme effects of poverty (AusAID 2009: 5).

The sacred value Ni-Vanuatu place on land, and the central role land plays in cultural identity, are enshrined in Chapter 12 of the Constitution, which articulates the underlying cultural principle of the inalienability of land and universal indigenous access to land for basic livelihoods. ${ }^{2}$ Consequently, all of Vanuatu's land legislation recognises the limitations of state governance of customary land. Formalised state protection of traditional land rights, until recently, was only possible in the case of land that was legally titled. Customary landholders governed non-titled land according to the rules of their kastom.

A number of development indicators illustrate that women in Vanuatu are disproportionately disadvantaged in society. There is limited access to education, with only 49 per cent of girls completing primary school and just 24 per cent commencing secondary school. In over 30 years of independence, Vanuatu has never had more than one or two female representatives, and currently has none at all, in a national parliament with 52 members. Vanuatu has one of the highest rates of gender-based violence in the world, with over 60 per cent of women experiencing violence (VWC 2011). Women's fertility remains high, with an average

1 See: data.worldbank.org/indicator/IQ.CPA.SOCI.XQ/countries.

2 Chapter 12 of the Constitution is devoted to land matters. Article 73 states that ' $[a] 11$ land in the Republic of Vanuatu belongs to the indigenous custom owners and their descendants', while Article 74 states that ' $[t]$ he rules of custom shall form the basis of ownership and use of land in the Republic of Vanuatu'. 
of 4.8 children per mother. While 61 per cent of working-age women participate in the workforce, a significant proportion work in the undocumented informal sector. Women typically access land and property through inheritance and marriage, but very few have recorded a formal claim to land. ${ }^{3}$ Nationally, only one in five households is headed by a woman (GoV 2009). The limited cash economy and poor access to credit in rural Vanuatu mean that there are few opportunities for women to earn cash or improve the standards of living of their families. The absence of women from representation in government and in the formal sector, and their limited access to services, point to women being particularly vulnerable in Vanuatu.

As a signatory to the Convention on the Elimination of All Forms of Discrimination against Women (CEDAW) since 1995, the Vanuatu government has been committed to advancing gender equality across several sectors, including that of land governance. However, gender equality has been largely viewed as a foreign import by the representatives of traditional societal structures. Existing land legislation is, at best, gender-neutral, with administrators typically adopting a (cultural) male bias in formal land titling and leasing (Scott et al. 2012). Women face several cultural barriers in exercising their rights to land, as exemplified by Merilyn Tahi's testimony to a Pacific regional meeting on women's access to adequate housing and land:

I was forced to marry a boy. I had one son and forced to care for three children adopted by my husband, and one son from another woman. I was married to him for 26 years ... he died in $1997 \ldots$ all my things were thrown out of my matrimonial house ... I have since found another partner ... [but] according to custom, because of the bride price, I should have remarried my husband's brother, uncle or nephews. So the uncle has vowed revenge if I re-marry someone else ... I still go to the island regularly with my son, but I do not go to my matrimonial home or my husband's family. My husband's sisters no longer speak to me. I have lost everything there (Tahi 2004: 137).

Women's rights to land are not independent of male relatives, and are an extension of their socially constructed gendered roles as daughters, sisters, wives or mothers (AusAID 2008: 82).

3 The Department of Lands does not disaggregate land leasing records by gender, but the author's own research has found that rural leases typically do not record Ni-Vanuatu women as lessors (except on Efate Island). In urban areas, the state is the lessor, and Ni-Vanuatu women may be included as joint lessees, but this is rare. 
This increases women's economic dependence on men, discouraging them from investing in land as a productive resource beyond subsistence farming, and denies women decision-making rights based on informed consent over land usage, investments and formal agreements on land rights (UNESCAP 2013: 149).

Advocates for women's rights in a male-dominated communitarian context must seek out an accepted cultural space to introduce women's matters into land discourse, overcoming exclusionary practices.

Central to this advocacy is a deep understanding of the nuances between access to land, in terms of rights-based advocacy, and the authority to decide on access to land, which focuses on the political dimensions of exclusion. Various studies have shown that most of Vanuatu's women have access to land in some form (Naupa and Simo 2008; GoV 2012b), but the ability to exert authority over this access is influenced by cultural norms and practice, both in the customary and formal domains. Hall, Hirsch and Li's (2011) framing of exclusion as a political process for determining access - including access to benefits-provides an appropriate lens for unpacking the advocacy approach taken in Vanuatu to elevate women's rights in the land reform agenda.

\section{Land Dualism}

As noted earlier, the Constitution of Vanuatu formally recognises the dual system of state and customary governance, particularly in relation to land matters. This dualism has led some (AusAID 2008; Naupa and Simo 2008; Naupa 2009; Stefanova et al. 2012; McDonnell 2013) to question which norms and practices take precedence, particularly where customary practices may conflict with state-condoned international best practice in matters such as women's rights.

Administratively, both the overlaps and differences between the two land governance systems often lead to conflict and confusion. As Rodman (1995) notes, uncertainty about who defines 'custom' lends itself to the emergence of 'masters of tradition' or political elites who direct or manipulate the modern interpretation of custom, and in so doing control it. In such a situation, the foundation of customary land tenure systems becomes challenged and further complicated by the overarching state land administration system that is limited in its ability to verify customary land claims. Siobhan McDonnell introduces the concept of 'masters of 
modernity'-men who are adept at negotiating the financial, cultural and, to a more limited degree, legal arrangements relating to land matters (see Chapter 9, this volume). This 'mastery' of the processes of the two systems affords certain men additional authority and privileges them as knowledge brokers or gatekeepers.

Where the two systems interact, such as when customary land parcels are formalised through the creation of a land title, a 'hybrid system' emerges that can embed the marginalisation of women in land matters, if rights are defined by the 'masters of modernity'. On many islands in Vanuatu, women do not have a formal role in traditional (or state) land matters, and where they do, this is becoming increasingly marginal (Naupa and Simo 2008). Competing interests in land further compound the ambiguous definition of kastom practice in a hybrid system. Whatever minimal protections for women's access to land may exist in traditional customs, which the state has lacked the capacity and the mechanism to enforce, become more threatened in the context of a land grab.

\section{The Global Land Grab Context}

Globally, land grabs have accounted for mass marginalisation of local populations, disenfranchised them of their land rights, and have occurred in contexts where the state imposes strict regulations over indigenous or customary land and retains the right to override the social institutions associated with it (Cotula et al. 2009). The displacement of settlements in the name of commerce, whether for large-scale agribusiness or extractive industries such as mining, has been viewed as a necessary price to pay for the greater economic benefit of states and multinational companies, but has also led to greater poverty in many cases, threatening the food security of the poor in particular (Daniel and Mittal 2009).

The global land grab literature and global campaigns to date have primarily addressed the ethics of land grabs or large-scale land investments, with some observers proposing a 'code of conduct' to regulate such land dealings (FAO et al. 2010). For example, Oxfam International's (2012) 'Behind the Brands' campaign has succeeded in getting major multinational brands (such as Coca-Cola) to commit to zero tolerance for land grabs by appealing to their corporate social responsibility. ${ }^{4}$

4 www.oxfam.org/en/grow/campaigns/behind-brands. 
The focus on transnational commercial land transactions is centred on the production and export of food, biofuel, timber and minerals, where there is a perception of foreign-induced land grabbing (Borras and Franco 2012). The emphasis on the role of external actors in the process has limited the attention paid to the role of domestic facilitators, national elites, and state institutions that enable large-scale access to land, both at a commercial and individual scale (Cotula et al. 2009; Borras and Franco 2010). In Vanuatu, the framing of land issues in terms of foreign-driven investments and deals, enabled by a weak government administration, has tended to overlook the role that traditional institutions and the 'masters of modernity' have played in facilitating these deals.

Verma (2014: 55) has observed that most of the land grab literature has been gender blind (but see Mackenzie 2010). Verma encourages closer scrutiny of the framing of land grab debates, which have tended to

focus on technocratic and productive values of land, stripping it of the multiple sociocultural, political, historical, and gendered meanings. This affects the processes by which women's and men's differential relationship, access, control, ownership, and security over land are negotiated (Verma 2014: 54).

This chapter explores the role of socially dominant groups and state bureaucrats in consolidating and expanding landholdings and selling or leasing them out to new investors, building on Borras and Franco's (2012) distinction between the de jure and de facto management of private property in land. It specifically looks at how this experience shaped particular gender advocacy strategies during Vanuatu's land reform process of the mid to late 2000s.

\section{Land Grabs and Vanuatu}

Vanuatu's 'land grab' experience is one of weakly enforced land legislation, unlike cases in the African region, and more recently in Papua New Guinea, where the government has strongly exerted its authority in facilitating large-scale land transactions for extractive industries. Vanuatu's 'zone of abandonment' in land governance, exemplified by the limited state oversight of land lease transactions negotiated between customary landowners and interested lessees — both foreign and domestic — is a direct product of Vanuatu's dual land governance system. The enshrining of 
customary land governance in the Constitution, combined with weak state legislation and regulation, has done little to protect traditional groups from the removal of their access to large tracts of land.

During the late 1990s through to the early 2000s, limited state monitoring enabled exponential growth in land transactions, mostly for speculative purposes. While almost 10 per cent of Vanuatu's land is under leasehold, this is primarily for residential purposes, reflective of the unique real estate emphasis of the 'land rush' during the early 2000s (Scott et al. 2012). The rising tensions between customary land groups and within families, as people-most often women-found themselves suddenly prevented from accessing garden lands, were the subject of much media coverage throughout the 2000s (see Kaloris 2009). Recognising the escalation of land conflict, the Vanuatu Cultural Centre convened a National Self-Reliance Summit in 2005, which led to a National Land Summit in 2006, hosted jointly with the Vanuatu government and the Malvatumauri (National Council of Chiefs). The National Land Summit passed 20 resolutions, committing the country to a long-term land reform process (Regenvanu 2008).

I was drawn into the land reform policy dialogue for both personal and intellectual reasons. As a mixed-race Ni-Vanuatu woman, I was aware that land had always been something that my male relatives talked about, not me. But in 2001, I became involved in researching traditional resource management for the Vanuatu Cultural Centre, which sparked an interest in researching the practical adaptations that occur when various pressures on community land management are prevalent. In the course of conducting research in the peri-urban village of Mele (for a Masters in Geography), it became apparent that I could not ignore the nexus between traditional and state land governance systems. By the time of the 2006 National Land Summit, I was one of only a small handful of women engaged in high-level discourse on this subject. This privilege was in part due to my previous employment at the Vanuatu Cultural Centre, my personal contacts within the Ministry of Lands from conducting my research, and my new job in the Australian government's Pacific Land Initiative. $^{5}$

5 This latter role drew both personal persecution from certain land rights activists who were suspicious of donors' interest in land reform, but also great opportunities to influence the land reform process to address gender issues and women's rights. Cox (2014) has pointed to the role of Melanesia's urban middle class in influencing politics and policy. Though not myself resident in town, I may have fallen into this category. 
While the 'land grab' in Vanuatu has largely been facilitated by internal-primarily indigenous-actors (the 'masters of modernity'), certain stakeholders were still focused on the popular framing of land reform to address the threat of foreign-induced land grabs. Framing the land reform process as a battle of 'us versus them', or 'Ni-Vanuatu versus foreigners', failed to recognise the role of indigenous middlemen, and did not allow for the heterogeneity of customary groups, nor the local political dynamics that shape land governance. This demarcation conceals women's rights behind a wholesale image of customary land tenure, and diverts public attention from the more pervasive challenge of local elite capture of custom and formal land governance processes. As a Ni-Vanuatu woman familiar with what Hall, Hirsch and Li (2011) call the 'intimate exclusions' that occur within customary land practice, I regularly advocated for a focus on indigenous facilitation of land grabs, but popular media rhetoric continually presented $\mathrm{Ni}$-Vanuatu as victims of land decisions, belying the active role that $\mathrm{Ni}$-Vanuatu men played in creating situations of land alienation. This framing challenge continues to the present day (Simo 2013).

\section{Gender and Land Context}

Eight years ago, my colleague Ketty Napwatt and I stood before an audience of 3,000 men in the national meeting hall of the traditional leaders who had gathered for the 2006 National Land Summit. This was my first public moment advocating for the protection of women's land rights - to speak about the unspoken. Until then, I had been working as a 'behind-the-scenes' policy maker, gathering evidence and applying it to Vanuatu's long-term land reform process. In Vanuatu culture, women do not speak before traditional chiefs; we certainly do not speak publicly in traditional meeting spaces, and we are invisible in land decisions. How then can we get women's perspectives included in the national land reform agenda when the space is typically male-dominated?

Introducing gender rights into the public discourse around land was not only made difficult by cultural attitudes and gendered roles, but also by the modalities of communication. A 2012 survey of citizens' information needs (InterMedia 2013) highlighted that the most preferred method of sharing information about land issues was in person (81 per cent), while radio was the second preferred method (68 per cent). If a trusted source is someone you know, the potential for distortion or influence in 
information flows is large. Any attempt to help increase women's awareness of their rights to land has to consider how to utilise these communication preferences. Addressing men, as the gatekeepers of knowledge and land decisions, is a prudent way to start to tackle the complex issue of land rights protection for Vanuatu's women.

\section{A Boost for Women's Land Rights: Passage of the Land Reform Act Amendments}

The recent amendments to the Land Reform Act signal an important step towards enhanced gender inclusion in the state and customary administration of land. The legislation ${ }^{6}$ is the culmination of a seven-year multi-stakeholder effort to formally protect women's land rights, although there is still much work to be done. Careful strategising enabled the attainment of this historic first step towards formalised social inclusion in a country struggling to balance the tension between the traditional and the modern, and between political elites and those without voice.

\section{Advocating for Women's Land Rights}

Globally, land rights advocacy typically adopts a cyclical approach of employing a highly visible 'upstream advocacy' that publicises the issue, and the less visible 'downstream advocacy' that involves building consensus, forging alliances, and lobbying. Land rights advocacy efforts have also involved a cyclical approach in which awareness raising and consensus building are followed by: building the capacity of women's organisations; the use of research to educate and mobilise support; various forms of public engagement; and the application of lessons learned to the next stage in the process (ANGOC 2010). ${ }^{7}$

In Vanuatu, advocacy for women's land rights has adopted similar approaches, but adapted to existing power dynamics and the cultural context. While the issue of focus was the protection of women's access to land, the emphasis was on mobilising men rather than women's organisations. This 'downstream' approach was essential to empowering

6 Land Reform (Amendment) Act no. 31 of 2013 and Land Lease (Amendment) Act no. 32 of 2013.

7 Some examples of global programs include Terrewode (Uganda), Landesa's Center for Women's Land Rights, and the International Land Coalition's program on Women's Land Rights (see also OHCHR and UN Women 2013). 
traditional male leaders to recognise, advocate and protect women's access to land resources. Efforts that began with an overtly public, 'upstream' gender advocacy effort would have hampered subsequent ability to engage male decision makers. Focusing efforts on those in power, rather than mobilising women's organisations, was equally important to ensuring that women's land rights became visible through formal state mechanisms. Commencing with research on traditional rights helped inform stakeholder engagement and mobilisation of men at all levels-from the grassroots to the national parliament. Women's mobilisation had to be the final step in order to ensure initial buy-in from the predominantly male decision makers (see Table 10.1).

The following account of this policy process is largely drawn from a paper presented at meeting on 'Good Practices in Realizing Women's Rights to Land' that was held in Switzerland, not Vanuatu (Naupa 2012).

Table 10.1 Timeline for gender advocacy efforts, 2006-13.

\begin{tabular}{|l|l|}
\hline Year & Milestone \\
\hline 2006 & $\begin{array}{l}\text { National Land Summit Resolutions recognise women's role in land matters } \\
\text { ('group ownership'). }\end{array}$ \\
\hline 2007 & $\begin{array}{l}\text { Research conducted on women's access to land in matrilineal societies } \\
\text { (Naupa and Simo 2008). }\end{array}$ \\
\hline 2008 & $\begin{array}{l}\text { Vanuatu Cultural Centre's Women Fieldworkers Workshop discusses } \\
\text { 'Women's Place on the Land'. }\end{array}$ \\
\hline 2010 & $\begin{array}{l}\text { Land Sector Framework 2009-2018 highlights inclusive decision-making } \\
\text { processes. }\end{array}$ \\
\hline $2011-13$ & $\begin{array}{l}\text { Justice for the Poor Program (World Bank/AusAID) conducts research on } \\
\text { group decision making about land on Epi Island (Porter and Nixon 2010). } \\
\text { integrate social inclusion into institutional policy and practice. }\end{array}$ \\
\hline 2013 & $\begin{array}{l}\text { Land Reform Act amendments foster inclusive decision making for lease- } \\
\text { based land transactions. }\end{array}$ \\
\hline
\end{tabular}

Source: Author's summary.

\section{Gathering Evidence for Advocacy Efforts}

Cultural resistance to gender equality in land matters can be addressed by sharing evidence of the negative impacts of women's exclusion from land decisions. In 2007 research was conducted on women's traditional roles in land decisions to gather evidence on cultural precedence for women's proactive roles in traditional land matters, led by the Vanuatu Cultural Centre with support from the Pacific Islands Forum Secretariat 
(Naupa and Simo 2008). This was followed by a 2008 Vanuatu Cultural Centre workshop focusing on women's voice in land matters. By gathering overwhelming evidence that refuted the received notion that decision making about land in Vanuatu was exclusively the realm of men, advocacy efforts could be tailored to make the land reform process more inclusive. Sustaining public attention on the issue required strategic use of the media in accentuating the challenges for women in the 'land for sale' environment on the main island of Efate.

In May 2009, the Cultural Centre's Land Desk gained the support of 100 chiefs to declare opposition to the government's initial land reform efforts through a 'Lamap Declaration' (MILDA 2009). ${ }^{8}$ Despite highlevel support from the Malvatumauri (the National Council of Chiefs), and its partnership with the Vanuatu government, there was still much suspicion surrounding any land reform efforts. According to the 'traditional guardians' camp, no land reform effort would be genuine without addressing the more fundamental problem of ministerial powers over customary land. However, procedurally, the inclusion of women and youth, as well as chiefs, in the Lamap Declaration was a good example of how to engage the broader community in land matters.

In 2010, the World Bank's Justice for the Poor program (called Jastis blong Evriwan in Bislama) collaborated with communities on the island of Epi to research the ways in which customary groups engage in the lease creation process and the subsequent impacts of this process on communities (Porter and Nixon 2010). Community theatre was used to communicate research findings and generate action at the local level. In 2011, the program conducted an assessment of the community dissemination of land leasing research, which found that communities most remembered:

the importance of land and its protection for future generations in the context of a growing population; the need for greater consultation and inclusive group decision-making regarding the leasing of land; the importance of transparent processes for customary landholder identification; the need to understand the social and environmental impact of leasing and obtain specialist advice to make informed decisions ... and the need for benefit-sharing within the group (World Bank n.d.).

8 In 2009, opposition to land reform efforts were generalised to encompass any effort by the Vanuatu government to modify the existing (although widely accepted by government as flawed) land administration arrangements. The specific land law reforms mentioned in the bulk of this chapter relate to efforts since 2009 . 
The value of this localised action research in triggering discussions about inclusive group decision making was considerable and timely, building on the momentum started by the Vanuatu Cultural Centre.

\section{Framing Gender Within Culture: Social Inclusion}

Fiercely nationalistic and supportive of the constitutional mandate of the primacy of customary governance systems over land, Vanuatu's traditional leaders have not responded positively in the past to a rights-based approach to gender and land. The framing of women's land rights within the context of family and community, and the broader social and cultural context, helped to gain a foothold in broader high-level discussions about customary land reform, offering a narrative of cultural continuity that sought to accommodate incremental advances for women (Naupa et al. 2006). Framing the issue as one of social inclusion, rather than 'just' a women's issue, tied advocacy efforts closer to culturally respected and valued principles relating to communal livelihoods. It helped to gain credibility for advocacy efforts, and also earned women a seat at the negotiating table for land reform. ${ }^{9}$

The strategic decision to focus on family units, rather than individuals, is one that has met with considerable success in other areas of women's rights. The Vanuatu Women's Centre's 11-year effort to introduce family protection legislation rested on principles of community peace and harmony, highlighting the importance of respect for women and therefore its importance in social cohesion. Working with nominated men and women who deliver community education activities and provide counselling and legal services (through Committees Against Violence Against Women), and a network of male advocates who conduct mento-men awareness on gender rights, the Centre has successfully integrated a women's rights issue into the social fabric of Ni-Vanuatu lives (Ellsberg et al. 2008: 173, 179-80). For advocacy efforts relating to women's land rights, targeted integration of women into key stages of decision-making processes will be an important next step.

9 The author subsequently served as a gender and land policy expert for the Vanuatu government's land reform agenda, was a member of the Vanuatu Land Governance Committee, and served as the Gender Adviser to the 2013 National Land Law Reform Committee. The last two were ministerial appointments. 


\section{Tapping into Networks of Power: Male Champions}

Advocating for women's land rights in a male-dominated culture necessitated a strategic emphasis on mobilising men rather than women to advocate for gender-sensitive land reform. As previously noted, the framing of the issue as a social-rather than gender-issue gave men a role to legitimately support the issue without undermining their own cultural standing. Ni-Vanuatu from both the traditional and state systems could 'buy in' to gender advocacy.

The Vanuatu government appointed a male gender focal point within the Department of Lands, who worked closely with long-time gender equality advocates, such as the author and the Department of Women's Affairs, to achieve a consensus from the traditional chiefly body to formally recognise and protect women's land rights in Vanuatu. The use of male champions enabled a truncated network influence effect that lobbying solely by women's organisations would have taken longer to achieve. ${ }^{10}$ This is a practice that women's organisations like the Vanuatu Women's Centre have also employed, using male advocates to champion an end to violence against women. In 2012, a citizens information survey revealed that 70 per cent of those surveyed believed land to be owned by groups, not individuals (InterMedia 2013), thus demonstrating growing public support for formalised social inclusion.

The gender focal point position within the Ministry of Lands ended in late 2013 due to budget constraints, but the importance of using and maintaining networks to ensure the sustainability of these advocacy efforts will remain central to the future effectiveness of the new Customary Land Management Act and the amendments to the Land Reform Act.

In the final quarter of 2013, the Ministry of Lands conducted a nationwide consultation and awareness campaign regarding a proposed Customary Land Management Act (as well as amendments to the Land Reform Act). This would introduce substantial changes to the formalisation process for customary land, not least the process of ownership identification (GoV 2013). Particular attention was paid to ensuring that, at each of the 24 consultation meetings, separate meetings were held with women. Two female staff were appointed to the consultation team to specifically

10 Advocacy by women's groups for family protection legislation in Vanuatu took 13 years to have an effect. 
facilitate these focused consultations with women on the land reform package. ${ }^{11}$ By clearly linking the 2006 National Land Summit resolutions to the proposed land law sections, providing informational material in Bislama, and adopting a multi-media campaign, the consultation process helped to build the momentum that culminated in the passing of the bill during the November 2013 parliamentary sitting. Importantly, these public consultations highlighted the point that, in determining group rights to land, 'women and youth have the right to participate in land decisions' (GoV 2013: 5), and that 'if people did not follow the law, any member of a custom land owning group (e.g., any woman or youth) had the right to make a formal complaint to the newly established Land Ombudsman' (ibid.: 29). The Minister for Lands, Ralph Regenvanu, and the President of the Malvatumauri, Chief Tirsupwe, led the consultations, demonstrating the political and cultural power that supported the inclusion of women's rights in land matters (Anon. 2013a). A month later, the traditional leaders of Vanuatu overwhelmingly supported the proposed legislation, which would also formally protect women's rights and roles in land decisions (Anon. 2013b).

\section{Other Factors: Who Frames the Agenda?}

Political commitment enabled the several years of groundwork for women's land rights to be realised. As one aspect of a broader-and contentious-land reform package, there were several moments when the achievement of formal protection of rights was threatened by differing views on traditional rights protection, and by competition from other land policy interests. The genuine fear of codification of customary law, and the potential for diminished flexibility in land rights, as well as a general suspicion of major land reform by the government, led some factions within the Vanuatu Cultural Centre to actively undermine efforts to formally institute protective mechanisms. ${ }^{12}$

11 Siobhan McDonnell, personal communication, September 2016.

12 For example, the Land Desk at the Vanuatu Cultural Centre (funded by The Christensen Fund) remained highly critical of government reform efforts throughout. 


\section{Closing the Circle}

Amendments to the Land Reform Act, gazetted in March 2014, elevate the role of women in consultation processes regarding custom and rights and public awareness of planned land transactions. Section 6(f3) states that:

Membership of the custom owner group must be determined according to the rules of custom and by customary processes and is to include all indigenous citizens (men, women and children) who hold ownership or use rights over land in accordance with the rules of custom.

And Section 6(j8) states that:

'affected groups' must include, but are not limited to all women and young people living in the area concerned, any indigenous citizens who are not custom owners and any community in whose locality the land is situated.

Explicit reference to women in ownership identification and negotiation discussions will be an important guide to land administrators. This is a significant gender equality achievement for Vanuatu's male-dominated culture.

However, while the Customary Land Management Act signals an important first step towards clarifying ambiguity in a hybrid land governance system, it prioritises customary control of land management over social inclusion. Its gender-neutral position with regards to defining land rights does not allow for clear implementation of its intent for an inclusive approach. Women are only mentioned once in the entire Act in relation to group affiliation, where Section 2(1) states that 'members of a nakamal include all men, women and children who come under the governance jurisdiction of that nakamal.

There is some irony in advocating social inclusion in land reform while inadvertently excluding women's organisations and networks. The advocacy strategy consciously focused on mobilising men, rather than women, to advocate for women's land rights, in an effort to be culturally sensitive, and therefore more accessible to powerful male decision makers. However, by delaying the focus on the organisational aspects of an advocacy model, Vanuatu now faces the problem of implementing gender-sensitive land law reform without the supporting organisational 
structures. There remains a role for the Department of Women's Affairs, which was consulted in the land reform process, women's organisations and networks of power, to maintain a focus on the rights issue, specifically through public 'upstream advocacy' efforts and to ensure the sustainability of law reform efforts to date.

The value of this important step in formalising protection of women's rights to land cannot be overemphasised. However, protecting rights to social inclusion in decision making on land-related matters is only part of a bigger package of legal reforms that are necessary to ensure complete protection. Family law, which will address marital property and inheritance concerns, is currently being developed and will demand greater participation by women's organisations and advocates with considerable cultural and formal experience in this area, such as the Vanuatu Women's Centre.

Beyond legal reforms, administrative reforms within both the Department of Lands and related land management entities (at both the state and local levels), as well as reforms within social institutions to incorporate women into traditional decision-making processes, have already begun. Standard policy implementation practices, such as public service training in operationalising legal roles and responsibilities, along with gender training, must be complemented by continued social inclusion campaigns via the media and chiefs' networks. Monitoring mechanisms to track policy implementation, such as six-monthly and annual agency reporting, should include gender-specific indicators to ensure that social inclusion remains visible in both practice and performance. Women's organisations should also play a role in monitoring implementation, using provincial and national networks to provide an independent assessment that can be used to inform improved government practice, through mechanisms like the CEDAW 'shadow reporting' process. Cross-sectoral resourcing of gender equality on land matters is essential for operationalising the current legislation.

Vanuatu's path to emphasise land tenure security for indigenous citizens has its pros and cons. On the one hand, group land rights have the potential to prevent and/or mitigate the negative implications of land grabs if private tenure security is guaranteed-a process that the Vanuatu government has now strengthened. On the other hand, unless the government strengthens its planning regulations and services, the lack of appropriate land advisory services to mitigate bad decisions by private 
group-based landholders may lead to a repeat of the land speculation of the early 2000s and women's continued exclusion from land decisions. However, the introduction of a set of formal mechanisms that require the involvement of women in the decision-making process goes some way towards mitigating against the lack of transparency in land decisions and the previous scant attention paid to the wider social implications of these land decisions.

\section{References}

ANGOC (Asian NGO Coalition for Agrarian Reform and Rural Development), 2010. 'Ideas in Action for Land Rights Advocacy.' Quezon City: ANGOC.

Anon., 2013a. 'Proposed Land Law Changes Consultation Takes Place.' Vanuatu Daily Post, 23 September.

— 2013b. 'Vanuatu's Chiefs Give the Go Ahead to New Land Reform Laws.' $A B C$ News, 18 October.

AusAID (Australian Agency for International Development), 2008. Making Land Work-Volume I: Reconciling Customary Land and Development in the Pacific. Canberra: AusAID.

— 2009. Vanuatu Land Program: Program Design Document. Canberra: AusAID. Viewed 15 December 2016 at: dfat.gov.au/about-us/ publications/Documents/vanuatu-land-program-design-document.pdf.

Borras, S.M. Jr and J.C. Franco, 2010. 'Towards a Broader View of the Politics of Global Land Grab: Rethinking Land Issues, Reframing Resistance.' Rotterdam: Erasmus University, Initiatives in Critical Agrarian Studies (Working Paper 1).

_ 2012. 'Global Land Grabbing and Trajectories of Agrarian Change: A Preliminary Analysis.' Journal of Agrarian Change 12: 34-59. doi. org/10.1111/j.1471-0366.2011.00339.x.

Cotula, L., S. Vermeulen, R. Leonard and J. Keeley, 2009. Land Grab or Development Opportunity? Agricultural Investment and International Land Deals in Africa. London: International Institute for Environment and Development. 
Cox, J., 2014. "'Grassroots", "Elites" and the New "Working Class" of Papua New Guinea.' Canberra: The Australian National University, State Society and Governance in Melanesia Program (Briefing Note 2014/6).

Daniel, S. and A. Mittal, 2009. 'The Great Land Grab: Rush for World's Farmland Threatens Food Security for the Poor.' Berkeley (CA): Oakland Institute.

Ellsberg, M., C. Bradley, A. Egan and A. Haddad, 2008. Violence Against Women in Melanesia and East Timor: Building on Global and Regional Promising Approaches. Canberra: AusAID.

FAO, IFAD, UNCTAD and World Bank, 2010. 'Principles for Responsible Agricultural Investment that Respects Rights, Livelihoods and Resources.' Discussion note. Viewed 15 December 2016 at: www. fao.org/fileadmin/templates/est/INTERNATIONAL-TRADE/FDIs/ RAI_Principles_Synoptic.pdf.

GoV (Government of Vanuatu), 2009. National Population and Housing Census_Gender Monograph: Women and Men in Vanuatu. Port Vila: National Statistics Office.

—, 2012a. Vanuatu Household Income and Expenditure Survey 2010: Report. Port Vila: National Statistics Office.

— , 2012b. Alternative Indicators of Well-Being in Melanesia: Vanuatu Pilot Study Report. Port Vila: National Statistics Office for Malvatumauri National Council of Chiefs.

—, 2013. 'Plan blong ol Jenis blong ol Loa blong Graon Folem ol Resolusen blong 2006 Nasonal Lan Samit.' Port Vila: Ministry of Lands.

Hall, D., P. Hirsch and T.M. Li, 2011. Powers of Exclusion: Land Dilemmas in Southeast Asia. Singapore: NUS Press.

InterMedia, 2013. 'Citizen Access to Information in Vanuatu: Land Issues.' Sydney: Intermedia for ABC International Development and AusAID.

Kaloris, R., 2009. 'Mangaliliu Road Block.' YouTube video, 2 February. Viewed 15 December 2016 at: www.youtube.com/ watch?v=zypGJpzLJIE. 
Mackenzie, F., 2010. 'Gender, Land Tenure and Globalisation: Exploring the Conceptual Ground.' In D. Tsikata and P. Golah (eds), Land Tenure, Gender and Globalisation: Research and Analysis from Africa, Asia and Latin America. Ottawa: International Development Research Center.

McDonnell, S., 2013. 'Exploring the Cultural Power of Land Law in Vanuatu: Law as a Performance That Creates Meaning and Identities.' Intersections 33.

MILDA (Melanesian Indigenous Land Defence Alliance), 2009. 'Lamap Declaration 2009.' Posted to MILDA website, 1 May. Viewed 16 December 2016 at: milda.aidwatch.org.au/resources/documents/ lamap-declaration-2009.

Naupa, A., 2009. 'iKastom iWomen and Land in Vanuatu.' Paper presented to the World Bank's 'Justice for the Poor Symposium on Legal Pluralism', Jakarta, 4-5 June.

_ 2012. 'Making Change Happen: How and Where to Realize Women's Land Rights in Vanuatu.' Paper presented to the Expert Group Meeting on 'Good Practices in Realizing Women's Rights to Productive Resources, with a Focus on Land', Geneva, 25-27 June.

Naupa, A., K. Napwatt and C. Sparks, 2006. 'Women and Land.' Paper presented at the National Land Summit, Port Vila, 25-29 September.

Naupa, A. and J. Simo, 2008. 'Matrilineal Land Tenure in Vanuatu"Hu i Kaekae long Basket?": Case studies of Raga and Mele.' In E. Huffer (ed.), Land and Women: The Matrilineal Factor. Suva: Pacific Islands Forum Secretariat.

OHCHR (Office of the UN High Commissioner for Human Rights) and UN Women, 2013. Realizing Women's Rights to Land and Other Productive Resources. New York and Geneva: OHCHR and UN Women.

Piau-Lynch, A., 2007. 'Vanuatu: Country Gender Profile.' Report to the Japan International Cooperation Agency. Viewed 15 December 2016 at: www.jica.go.jp/english/our_work/thematic_issues/gender/ background/pdf/e07van.pdf. 
Porter, R. and R. Nixon, 2010. 'Wan Lis, Fulap Stori: Leasing on Epi Island, Vanuatu.' Washington (DC): World Bank, Justice for the Poor Program (Research Report).

Regenvanu, R., 2008. 'Issues with Land Reform in Vanuatu.' Journal of South Pacific Law 12: 63-67.

Rodman, M.C., 1995. 'Breathing Spaces: Customary Land Tenure in Vanuatu.' In R.G. Ward and E. Kingdon (eds), 1995. Land, Custom and Practice in the South Pacific. Cambridge: Cambridge University Press. doi.org/10.1017/cbo9780511597176.004.

Scott, S., M. Stefanova, A. Naupa and K. Vurobaravu, 2012. 'Vanuatu National Leasing Profile: A Preliminary Analysis.' Washington (DC): World Bank, Justice for the Poor Program (Briefing Note 7.1).

Simo, J., 2013. 'Indigenous People, Not Australians, Should Determine Vanuatu's Future.' Sydney Morning Herald, 19 November.

Stefanova, M., R. Porter and R. Nixon, 2012. 'Towards More Equitable Land Governance in Vanuatu: Ensuring Fair Dealings for Customary Groups.' Washington (DC): World Bank, Justice for the Poor Program (Discussion Note).

Tahi, M., 2004. 'Testimonies on Violence against Women and the Right to Housing (Vanuatu).' In A.G. Aggarwal, S. Chaudhry and P. Waran (eds), Our Land, Our Homes, Our Culture, Our Human Rights. Nadi (Fiji): Proceedings of the Pacific Regional Consultation on 'Women's Rights to Adequate Housing and Land'.

Tor, R. and A. Toka, 2004. 'Gender, Kastom and Domestic Violence in Vanuatu: A Research on the Historical Trend, Extent and Impact of Domestic Violence in Vanuatu.' Report to the Vanuatu Department of Women's Affairs.

UNESCAP (UN Economic and Social Commission for Asia and the Pacific), 2013. Statistical Yearbook for Asia and the Pacific 2013. Bangkok: UNESCAP.

Verma, R., 2014. 'Land Grabs, Power and Gender in Eastern and Southern Africa: So, What's New?' Feminist Economics 20: 52-75. doi.org/10.10 80/13545701.2014.897739. 
VNGOC (Vanuatu NGO Consortium), 2007. Vanuatu NGO Shadow Report on the Implementation of the Convention on the Elimination of All Forms of Discrimination Against Women. Port Vila: VNGOC.

VWC (Vanuatu Women's Centre), 2011. Vanuatu National Survey on Women's Lives and Family Relationships. Port Vila: VWC.

World Bank, n.d. 'Drama and Legal Awareness Are Effective Tools to Engage Communities Around Land Issues in Vanuatu.' Washington (DC): World Bank, Justice for the Poor Program. Viewed 15 December 2016 at: go.worldbank.org/Z66V7376M0. 
This text is taken from Kastom, property and ideology: Land transformations in Melanesia, edited by Siobhan McDonnell, Matthew Allen and Colin Filer, published 2017 by ANU Press, The Australian National University, Canberra, Australia. 